\title{
ANALISIS KESALAHAN SISWA KELAS V SDN PENGAWU DALAM MENYELESAIKAN SOAL CERITA PADA OPERASI HITUNG PECAHAN
}

\author{
Indah Suciati \\ Program Studi Pendidikan Matematika Universitas Alkhairaat Palu \\ ndahmath@gmail.com
}

\begin{abstract}
ABSTRAK
Penelitian ini bertujuan untuk mendeskripsikan dan menganalisis kesalahan siswa dalam menyelesaikan soal pada materi operasi hitung pecahan. Jenis penelitian yang digunakan adalah penelitian deskriptif eksploratif dengan pendekatan campuran (mixed methods). Populasi penelitian ini adalah siswa kelas V SDN Pengawu dengan jumlah subjek penelitian sebesar 35 siswa. Hasil penelitian diperoleh bahwa kesalahan yang paling banyak dilakukan siswa yaitu Process Skills Errors sebesar 40,25\%. Selanjutnya diikuti oleh Tranformasion Errors sebesar 26,97\%, Comprehension Errors sebesar 19,09\%, Encoding Errors sebesar 5,39\%, dan Reading Errors sebesar 4,56\%, serta Careless dilakukan sebesar 3,73\%. untuk operasi penjumlahan pecahan, kesalahan yang paling banyak dilakukan adalah Process Skills Errors sebesar 49,23\%. Untuk operasi pengurangan pecahan, kesalahan yang paling banyak dilakukan adalah Tranformation Errors sebesar 52,31\%. Operasi perkalian pecahan, kesalahan yang paling banyak dilakukan adalah Tranformation Errors sebesar 27,69\%. Dan untuk operasi pembagian pecahan, kesalahan yang paling banyak dilakukan adalah Process Skills Errors sebesar 40,00\%.
\end{abstract}

Kata kunci : analisis kesalahan, Newman, operasi hitung pecahan

\begin{abstract}
This study aims to describe and analyze students' errors in solving problems in fractional counting operations. The type of research used is explorative descriptive research with mixed methods. The population of this study was the fifth grade students of Pengawu Elementary School with the number of research subjects amounting to 35 students. The results showed that the most mistakes made by students were Process Skills Errors of $40.25 \%$. Then followed by Tranformasion Errors by $26.97 \%$, Comprehension Errors by $19.09 \%$, Encoding Errors by $5.39 \%$, and Reading Errors by $4.56 \%$, and Careless by $3.73 \%$. for fractional addition operations, the most common error was Process Skills Errors of $49.23 \%$. For fractional reduction operations, the most common error is Tranformation Errors of $52.31 \%$. Fractional multiplication operations, the most common error is Tranformation Errors of $27.69 \%$. And for fraction sharing operations, the most common mistake is Process Skills Errors of $40.00 \%$.
\end{abstract}

Keywords: analysis of errors, Newman, fractional counting operations. 


\section{PENDAHULUAN}

Dalam dunia pendidikan saat ini, khususnya untuk tingkatan Sekolah Dasar, hampir semua sekolah menggunakan kurikulum 2013, dimana soal cerita pada mata pelajaran matematika tak asing lagi untuk siswa sekolah dasar tersebut. Soal cerita menuntut siswa untuk dapat berpikir kritis karena siswa diminta untuk dapat menganalisis soal dengan baik, bagaimana cara pemecahan masalahnya atau solusi maupun jawabannya. Sehingga itu, tak jarang siswa melakukan kesalahan-kesalahan dalam menjawab soal atau masalah yang diberikan. Hal ini sejalan dengan temuan pada penelitian Juliyanti (2016:121) yang menyatakan bahwa siswa paling banyak melakukan kesalahan dalam memahami masalah saat mengerjakan soal cerita. Oleh karena itu, banyak siswa yang memiliki nilai yang rendah. Sesuai dengan pendapat Lusiana (2017:25) bahwa dengan adanya kesalahan yang dilakukan siswa dapat menimbulkan penurunan nilai pada mata pelajaran matematika.

Dalam mata pelajaran matematika tingkat Sekolah Dasar terdapat materi tentang operasi hitung pecahan. Materi pecahan merupakan salah satu materi yang sering terdapat kesalahan yang dilakukan oleh siswa. Pecahan merupakan salah satu materi yang dianggap sulit oleh siswa, padahal materi pecahan sering kita jumpai dan digunakan dalam kehidupan sehari-hari. Menurut Setiyasih (Saputro, 2016:63) bahwa kesalahan siswa dalam operasi hitung pecahan, antara lain untuk kesalahan operasi penjumlahan sebesar 5,49\%, kesalahan pengurangan sebesar $23,08 \%$, dan kesalahan dalam operasi perkalian sebesar $53,85 \%$, serta kesalahan dalam operasi pembagian sebesar $14,28 \%$. Sesuai juga dengan pendapat Idris dan Narayanan (2011) yang melakukan penelitian pada 80 siswa kelas II SMP di negara bagian Selangor. Temuan penelitian ini menunjukkan bahwa kesalahan dalam operasi penjumlahan ialah 29,8\%, kesalahan kecerobohan/kelalaian adalah 26,3\%, dan kesalahan acak 11,1\%. Dalam kesalahan sistematis, 50,6\% siswa memiliki masalah konversi, 26,2\% mengalami masalah dalam pemahaman, dan $14,9 \%$ berkaitan dengan menyelesaikan masalah pecahan dengan tidak tepat. Adapun pengurangan pecahan, terdapat 26,4\% kesalahan sistematis, $10,3 \%$ kesalahan kecerobohan/kelalaian, dan 2,5\% kesalahan acak. Dalam kesalahan sistematis 47,9\% siswa menghadapi masalah dalam hal pemahaman.

Materi operasi hitung pecahan merupakan salah satu materi yang cukup rumit, sehingga peluang terjadinya kesalahan pada siswa sangat besar terjadi apalagi jika operasi hitung pecahan disajikan dalam bentuk soal cerita. Adapun tipe-tipe kesalahan menurut Newman (Amalia, 2017) yang sering dilakukan siswa yaitu: (1) Reading Errors, yaitu siswa membuat kesalahan dalam membaca kata-kata penting dalam pertanyaan dari soal yang diberikan atau siswa salah dalam membaca informasi utama, sehingga tidak menggunakan informasi tersebut untuk menyelesaikan soal yang mengakibatkan kesalahan selanjutnya, (2) Comprehension Errors, yaitu siswa sebenarnya dapat memahami soal tetapi belum menangkap informasi yang terkandung dalam pertanyaan tersebut, sehingga siswa tidak dapat memproses lebih lanjut solusi dari permasalahan itu, (3) Tranformation Errors, yaitu siswa telah mampu memahami apa yang menjadi pertanyaan dari suatu masalah matematika, akan tetapi tidak mampu mengidentifikasi operasi atau urutan operasi yang diperlukan untuk menyelesaikan masalah, (4) Process Skills Errors, yaitu siswa dapat mengenali operasi yang sesuai atau urutan operasi, tetapi tidak mengetahui prosedur yang diperlukan untuk melakukan operasi secara akurat, dan (5) Encoding Errors, yaitu siswa dapat menyelesaikan masalah tetapi tidak mampu menyatakan 
solusi dalam bentuk notasi yang benar dan bisa diterima sebagai suatu kesimpulan. Dengan kata lain, siswa mampu menyelesaikan permasalahan, tetapi dalam melakukan penyimpulan jawaban tidak sesuai dengan permintaan soal. Hal ini sejalan dengan temuan Abdullah, dkk (2015) yang melaksanakan penelitian terhadap 96 siswa sekolah menengah di Johor. Hasil penelitiannya menunjukkan bahwa siswa sering membuat kesalahan dalam pengkodean $(27,58 \%)$, keterampilan proses $(27,33 \%)$, transformasi $(24,17 \%)$ dan pemahaman $(20,92 \%)$. Hasil temuannya menunjukkan bahwa siswa menghadapi masalah untuk menghubungkan informasi dan implementasi strategi yang digunakan dalam memecahkan masalah pecahan yang melibatkan HOTS. Temuan di atas juga sejalan dengan temuan penelitian Cahyono (2017) yang menyatakan bahwa kesalahan yang dilakukan siswa dalam mengerjakan soal cerita pada materi pecahan yaitu untuk kesalahan memahami masalah sebesar 15,95\%, kesalahan transformasi sebesar 28,4\%, kesalahan perhitungan sebesar $63,6 \%$ dan kesalahan penarikan kesimpulan sebesar $50 \%$.

Dengan berbagai jenis kesalahan yang dapat terjadi dalam menyelesaikan soal cerita yang berkaitan dengan operasi hitung pecahan, maka kesalahan-kesalahan tersebut perlu dianalisis untuk mengetahui kesalahan apa saja yang sering dilakukan khususnya pada siswa Sekolah Dasar. Analisis kesalahan membantu guru sebagai bahan pertimbangan dalam menentukan pemilihan model atau metode pengajaran yang tepat untuk meminimalisir terjadinya kesalahan yang berulang yang sering dilakukan siswa Sekolah Dasar. Hal ini sesuai dengan pendapat Herholdt dan Sapire (2014) yang mengemukakan bahwa analisis kesalahan yaitu studi tentang kesalahan dalam pekerjaan siswa dengan tujuan mencari kemungkinan penjelasan untuk kesalahan tersebut. Analisis kesalahan adalah aktivitas multifaset yang melibatkan analisis yang benar, sebagian proses yang benar dan salah dan memikirkan kemungkinan strategi penyelesaian.

Penelitian ini bertujuan untuk mendeskripsikan dan menganalisis kesalahan siswa kelas V SD Negeri Pengawu dalam menyelesaikan soal cerita pada materi operasi hitung pecahan.

\section{METODE}

Jenis penelitian ini yaitu penelitian deskriptif eksploratif dengan menggunakan pendekatan campuran (mixed methods) yang merupakan perpaduan antara pendekatan kualitatif dan kuantitatif (Sugiyono, 2013). Desain penelitian yang dipilih yaitu sequential explanatory design, dengan karakteristik dari desain ini ialah pengumpulan dan analisis data kuantitatif yang diikuti dengan pengumpulan dan analisis data kualitatif. Oleh karena itu, langkah pertama dalam penelitian ini ialah mengumpulkan dan menganalisis data kuantitatif berupa persentase kesalahan siswa yang diikuti dengan mengumpulkan dan menganalisis data kualitatif berupa uraian keadaan atau kesalahan yang dilakukan oleh siswa.

Populasi penelitian ini adalah Siswa kelas V SDN Pengawu tahun pelajaran 2017/2018. Berdasarkan data yang diperoleh dari SDN Pengawu, maka jumlah seluruh siswa kelas V adalah 65 siswa dari 2 kelas. Karena Dalam penelitian ini jumlah populasi kurang dari 100 siswa maka penelitian yang dilakukan adalah penelitian populasi. Penentuan subjek penelitian berdasarkan hasil tes diagnostik pada materi operasi hitung pecahan. Siswa yang memiliki nilai tidak mencapai Kriteria Ketuntasan Minimal yaitu 60 dipilih sebagai subjek penelitian. Berdasarkan hasil tes diagnostik dari 65 siswa, maka terpilih 35 siswa yang menjadi subjek 
penelitian yang diwawancarai untuk mengetahui kesalahan-kesalahan yang dilakukan dalam menyelesaikan soal cerita yang berkaitan dengan operasi hitung pecahan.

Teknik pengumpulan data yang digunakan berupa: 1) Tes diagnostik, yaitu tes untuk mengetahui kesalahan siswa dalam menyelesaikan soal cerita pada materi operasi hitung pecahan. Tes yang diberikan adalah tes berbentuk uraian (soal cerita) yang berkaitan dengan operasi hitung pecahan. 2) Wawancara yang dilakukan untuk memperoleh informasi lebih lanjut tentang kesalahan siswa dalam menyelesaikan soal cerita yang berkaitan dengan operasi hitung pecahan. Pertanyaan-pertanyaan yang diajukan pada saat wawancara tidak dibuat secara berstruktur, tetapi bersumber dari hasil pekerjaan siswa dan jawaban-jawaban yang muncul dari pertanyaan sebelumnya.

Teknik analisis data yang digunakan ada 2, yaitu :

1) Analisis data kualitatif, dengan data yang akan dianalisis berasal dari hasil tes diagnostik dan wawancara. Data tersebut dianalisis dengan menggunakan model alur yang mengacu kepada Miles dan Huberman (Suciati, 2010:25-26) yaitu:

a) Mereduksi data (proses kegiatan menyelesaikan, memfokuskan dan menyederhanakan data dimulai dari awal pengumpulan data hingga penyusunan laporan, sehingga data tersebut dapat memberikan deskripsi yang lebih jelas tentang hasil tes diagnostik dan wawancara),

b) Penyajian data

Penyajian data dilakukan dengan menyusun secara naratif sekumpulan informasi yang telah dilakukan dari hasil reduksi, sehingga dapat memberikan kemungkinan penarikan kesimpulan dan pengambilan tindakan. Dari data yang telah disajikan, selanjutnya dibuat penafsiran dan dievaluasi.

c) Penarikan kesimpulan.

Penarikan kesimpulan dimaksudkan untuk memberikan kesimpulan terhadap hasil penelitian dan penafsiran serta evaluasi. Penarikan kesimpulan merupakan pengungkapan akhir dari hasil mengenai kesalahan siswa kelas $\mathrm{V}$ SDN Pengawu pada soal cerita operasi hitung pecahan.

2) Analisis Data Kuantitatif

Data juga dianalisis secara kuantitatif untuk mengetahui tingkat persentasi kesalahan siswa pada soal cerita operasi hitung pecahan.

\section{HASIL DAN PEMBAHASAN}

Langkah pertama dalam penelitian ini adalah dengan memberikan tes diagnostik untuk mengetahui kesalahan siswa dalam operasi hitung pecahan. Hasil dari tes diagnostik dijabarkan pada tabel berikut ini:

Tabel 1. Hasil tes diagnostik peritem dari 65 siswa

\begin{tabular}{ccccc}
\hline $\begin{array}{c}\text { Nomor } \\
\text { soal }\end{array}$ & $\begin{array}{c}\text { Jumlah siswa } \\
\text { yang menjawab } \\
\text { benar }\end{array}$ & Persentase & $\begin{array}{c}\text { Jumlah siswa } \\
\text { yang menjawab } \\
\text { salah }\end{array}$ & Persentase \\
\hline 1. & 53 & $81,54 \%$ & 12 & $18,46 \%$ \\
2. & 24 & $36,92 \%$ & 41 & $63,08 \%$ \\
3. & 48 & $73,85 \%$ & 17 & $26,15 \%$ \\
4. & 10 & $15,38 \%$ & 55 & $84,62 \%$ \\
5. & 21 & $32,31 \%$ & 44 & $67,69 \%$ \\
6. & 1 & $1,54 \%$ & 64 & $98,46 \%$ \\
\hline
\end{tabular}


Dari tabel 1 di atas, terlihat bahwa soal nomor 1 adalah soal yang paling banyak dijawab benar oleh siswa, yaitu 53 orang atau 81,54\%. Urutan kedua adalah soal nomor 3 yang dapat dijawab benar oleh 48 siswa atau 73,85\%. Soal nomor 1 merupakan soal cerita yang berkaitan dengan operasi penjumlahan pecahan yang mempunyai penyebut sama, sedangkan soal nomor 3 merupakan soal cerita yang berkaitan dengan operasi pengurangan pecahan yang mempunyai penyebut sama. Hal ini berarti, siswa lebih paham terhadap soal mengenai operasi penjumlahan pecahan yang mempunyai penyebut sama daripada soal mengenai operasi pengurangan pecahan yang mempunyai penyebut sama.

Dari tabel juga terlihat bahwa soal nomor 6 adalah soal yang paling sedikit dijawab benar oleh siswa, yaitu 1 orang atau 1,54\%. Urutan kedua adalah soal nomor 4 yaitu dapat dijawab benar oleh 10 siswa atau 15,38\%. Soal nomor 6 merupakan soal cerita yang berkaitan dengan operasi pembagian pecahan, sedangkan soal nomor 4 merupakan soal cerita yang berkaitan dengan operasi pengurangan pecahan yang penyebutnya tidak sama. Hal ini berarti, diantara semua soal yang berkaitan dengan operasi hitung pecahan, soal cerita mengenai pembagian pecahan yang dianggap paling sulit oleh siswa.

Setelah dilakukan tes diagnostik terhadap 65 siswa, selanjutnya dilakukan pemilihan subjek penelitian yang akan diwawancarai mengenai kesalahan yang dilakukan saat menjawab tes diagnostik. Pemilihan subjek penelitian berdasarkan nilai Kriteria Ketuntasan Minimal yaitu 60. Jika nilai siswa di bawah nilai 60, maka mereka terpilih sebagai subjek penelitian. Berdasarkan hasil tes diagnostik, maka terpilih 35 orang siswa yang menjadi subjek penelitian.

Setelah melaksanakan wawancara terhadap 35 orang siswa, maka didapatkan berbagai kesalahan-kesalahan pada operasi hitung pecahan yang dapat dilihat pada tabel berikut ini:

Tabel 2. Pengelompokkan kesalahan siswa pada operasi hitung pecahan

\begin{tabular}{|c|c|c|c|c|c|c|c|}
\hline No. & $\begin{array}{l}\text { Operasi } \\
\text { hitung } \\
\text { pecahan }\end{array}$ & $\begin{array}{c}\text { Reading } \\
\text { Errors }\end{array}$ & $\begin{array}{c}\text { Comprehension } \\
\text { Errors }\end{array}$ & & $\begin{array}{c}\text { Tranformation } \\
\text { Errors }\end{array}$ & $\begin{array}{c}\text { Process Skills } \\
\text { Errors }\end{array}$ & $\begin{array}{c}\text { Encoding } \\
\text { Errors }\end{array}$ \\
\hline $\begin{array}{l}1 \\
\text {. }\end{array}$ & $\begin{array}{l}\text { Operasi } \\
\text { penjumlahan } \\
\text { pada } \\
\text { pecahan } \\
\text { yang } \\
\text { berpenyebut } \\
\text { sama }\end{array}$ & $\begin{array}{l}\text { Tidak } \\
\text { menuliskan } \\
\text { apa yang } \\
\text { diketahui dan } \\
\text { apa yang } \\
\text { ditanyakan }\end{array}$ & $\begin{array}{l}\text { Tidak memahami } \\
\text { maksud soal, } \\
\text { sehingga tidak } \\
\text { menjawab soal. }\end{array}$ & 1) & $\begin{array}{l}\text { Tidak mampu } \\
\text { mengubah bentuk } \\
\text { soal ke dalam } \\
\text { model matematika } \\
\text { Tidak memiliki ide } \\
\text { untuk } \\
\text { menyelesaikan soal, } \\
\text { sehingga } \\
\text { menuliskan } \\
\text { berbegai jenis } \\
\text { pecahan. }\end{array}$ & $\begin{array}{l}\text { 1) } \begin{array}{l}\text { Nilai pembilang } \\
\text { dijumlahkan dan } \\
\text { nilai penyebut }\end{array} \\
\text { juga dijumlahkan. } \\
\text { 2) Nilai penyebut } \\
\text { dijumlahkan } \\
\text { kemudian menjadi } \\
\text { nilai pembilang } \\
\text { pada hasil operasi. } \\
\text { Karena nilai } \\
\text { penyebutnya } \\
\text { berjumlah dua, } \\
\text { maka dua } \\
\text { merupakan nilai } \\
\text { penyebut dari hasil } \\
\text { operasi. }\end{array}$ & 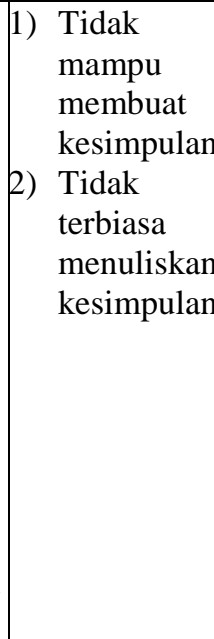 \\
\hline 2 & $\begin{array}{l}\text { Operasi } \\
\text { penjumlahan } \\
\text { pada pecahan } \\
\text { yang }\end{array}$ & $\begin{array}{l}\text { Tidak } \\
\text { menuliskan } \\
\text { apa yang } \\
\text { diketahui }\end{array}$ & $\begin{array}{l}\text { Tidak memahami } \\
\text { maksud soal, } \\
\text { sehingga tidak } \\
\text { menjawab soal. }\end{array}$ & 1) & $\begin{array}{l}\text { Tidak mampu } \\
\text { mengubah bentuk } \\
\text { soal ke dalam } \\
\text { model matematika }\end{array}$ & $\begin{array}{l}\text { 1) Nilai pembilang } \\
\text { dijumlahkan dan } \\
\text { nilai penyebut juga } \\
\text { dijumlahkan. }\end{array}$ & $\begin{array}{l}\text { 1) Tidak } \\
\text { mampu } \\
\text { membuat } \\
\text { kesimpulan }\end{array}$ \\
\hline
\end{tabular}




\begin{tabular}{|c|c|c|c|c|c|c|c|}
\hline & $\begin{array}{l}\text { berpenyebut } \\
\text { berbeda }\end{array}$ & $\begin{array}{l}\text { dan apa } \\
\text { yang } \\
\text { ditanyakan }\end{array}$ & & & $\begin{array}{l}\text { Tidak paham } \\
\text { dengan operasi } \\
\text { penjumlahan } \\
\text { pecahan } \\
\text { berpenyebut } \\
\text { berbeda, sehingga } \\
\text { mengalikan nilai } \\
\text { pembilang dan } \\
\text { mengalikan nilai } \\
\text { penyebut. }\end{array}$ & $\begin{array}{l}\text { 2) Nilai pembilang } \\
\text { dijumlahkan dan } \\
\text { untuk nilai penyebut } \\
\text { menggunakan nilai } \\
\text { penyebut pada } \\
\text { pecahan kedua. } \\
\text { 3) Melakukan } \\
\text { penyamaan nilai } \\
\text { penyebut terlebih } \\
\text { dahulu, kemudian } \\
\text { langsung } \\
\text { menjumlahkan nilai } \\
\text { pembilang tanpa } \\
\text { mengubah ke } \\
\text { pecahan senilai } \\
\text { terlebih dahulu. } \\
\text { 4)Menjumlahkan nilai } \\
\text { pembilang dan } \\
\text { mengambil nilai } \\
\text { penyebut pada } \\
\text { pecahan pertama. }\end{array}$ & $\begin{array}{l}\text { 2) Tidak } \\
\text { terbiasa } \\
\text { menuliskan } \\
\text { kesimpulan } \\
\end{array}$ \\
\hline 3 & $\begin{array}{l}\text { Operasi } \\
\text { pengurangan } \\
\text { pada } \\
\text { pecahan } \\
\text { yang } \\
\text { berpenyebut } \\
\text { sama }\end{array}$ & $\begin{array}{l}\text { Tidak } \\
\text { menuliskan } \\
\text { apa yang } \\
\text { diketahui } \\
\text { dan apa } \\
\text { yang } \\
\text { ditanyakan }\end{array}$ & $\begin{array}{l}\text { Tidak memahami } \\
\text { maksud soal, } \\
\text { sehingga tidak } \\
\text { menjawab soal. }\end{array}$ & 1) & $\begin{array}{l}\text { Tidak mampu } \\
\text { mengubah bentuk } \\
\text { soal ke dalam } \\
\text { model matematika } \\
\text { Tidak paham } \\
\text { dengan operasi, } \\
\text { sehingga } \\
\text { mengambil nilai } \\
\text { pada pecahan } \\
\text { pertama. } \\
\text { Tidak memahami } \\
\text { operasi yang } \\
\text { digunakan, } \\
\text { sehingga } \\
\text { mengalikan nilai } \\
\text { pembilang dan } \\
\text { nilai penyebut. } \\
\text { Tidak paham } \\
\text { dengan operasi } \\
\text { yang digunakan, } \\
\text { sehingga } \\
\text { menjumlahkan } \\
\text { nilai pembilang } \\
\text { dan menjumlahkan } \\
\text { nilai penyebut. } \\
\text { Tidak paham } \\
\text { dengan operasi } \\
\text { yang digunakan, } \\
\text { sehingga langsung } \\
\text { menjumlahkan } \\
\text { nilai pembilang. }\end{array}$ & $\begin{array}{l}\text { 1) Nilai pembilang } \\
\text { dikurangkan dan } \\
\text { nilai penyebut } \\
\text { juga dikurangkan. }\end{array}$ & 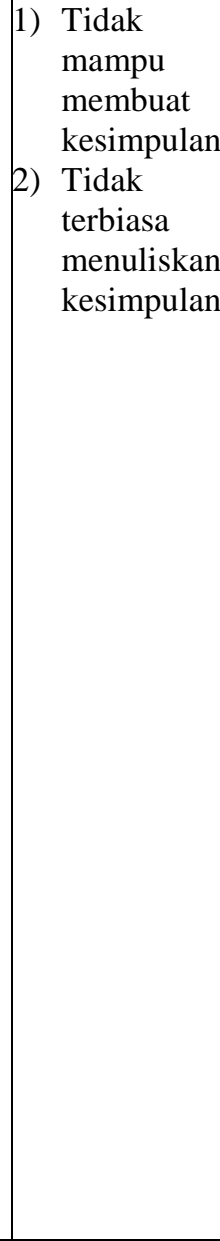 \\
\hline 4 & $\begin{array}{l}\text { Operasi } \\
\text { pengurangan } \\
\text { pada } \\
\text { pecahan } \\
\text { yang }\end{array}$ & $\begin{array}{l}\text { Tidak } \\
\text { menuliskan } \\
\text { apa yang } \\
\text { diketahui } \\
\text { dan apa }\end{array}$ & $\begin{array}{l}\text { Tidak memahami } \\
\text { maksud soal, } \\
\text { sehingga tidak } \\
\text { menjawab soal. }\end{array}$ & 1) & $\begin{array}{l}\text { Tidak mampu } \\
\text { mengubah bentuk } \\
\text { soal ke dalam } \\
\text { model matematika } \\
\text { Tidak memahami }\end{array}$ & $\begin{array}{l}\text { 1) Nilai pembilang } \\
\text { dikurangkan dan } \\
\text { nilai penyebut juga } \\
\text { dikurangkan (nilai } \\
\text { penyebut pada }\end{array}$ & 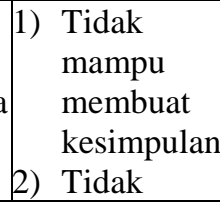 \\
\hline
\end{tabular}




\begin{tabular}{|c|c|c|c|c|c|c|}
\hline $\begin{array}{l}\text { berpenyebut } \\
\text { berbeda }\end{array}$ & $\begin{array}{l}\text { yang } \\
\text { ditanyakan }\end{array}$ & 3 & 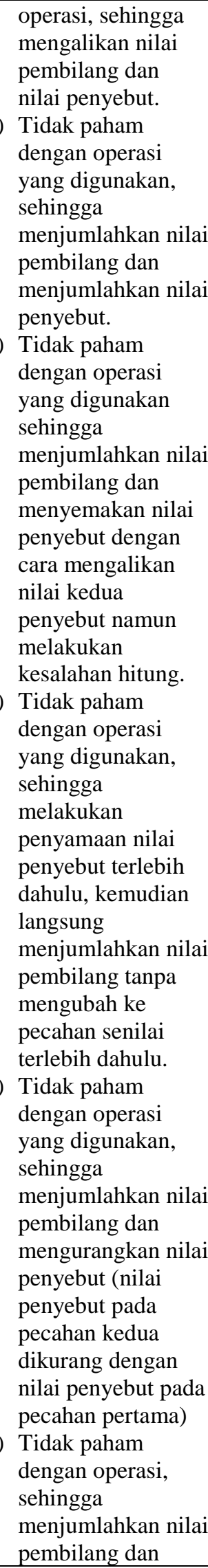 & i) & $\begin{array}{l}\text { pecahan kedua } \\
\text { dikurangi nilai } \\
\text { penyebut pada } \\
\text { pecahan pertama) } \\
\text { Melakukan } \\
\text { penyamaan } \\
\text { penyebut terlebih } \\
\text { dahulu, kemudian } \\
\text { langsung } \\
\text { mengurangkan } \\
\text { nilai pembilang } \\
\text { tanpa mengubah } \\
\text { ke pecahan senilai } \\
\text { terlebih dahulu. } \\
\text { Mengurangkan } \\
\text { nilai pembilang } \\
\text { dan mengambil } \\
\text { nilai penyebut } \\
\text { yang besar (nilai } \\
\text { penyebut pada } \\
\text { pecahan kedua). }\end{array}$ & $\begin{array}{l}\text { terbiasa } \\
\text { menuliskan } \\
\text { kesimpulan }\end{array}$ \\
\hline
\end{tabular}




\begin{tabular}{|c|c|c|c|c|c|c|c|c|}
\hline & & & & & $\begin{array}{l}\text { mengalikan nilai } \\
\text { penyebut. } \\
\text { Tidak paham } \\
\text { dengan operasi, } \\
\text { sehingga } \\
\text { menyamakan nilai } \\
\text { penyebut, } \\
\text { kemudian } \\
\text { mengubah pecahan } \\
\text { menjadi pecahan } \\
\text { senilai, namun } \\
\text { menggunakan } \\
\text { operasi } \\
\text { penjumlahan. }\end{array}$ & & & \\
\hline 5 & $\begin{array}{l}\text { Operasi } \\
\text { perkalian } \\
\text { pecahan }\end{array}$ & $\begin{array}{l}\text { Tidak } \\
\text { menuliskan } \\
\text { apa yang } \\
\text { diketahui } \\
\text { dan apa } \\
\text { yang } \\
\text { ditanyakan }\end{array}$ & $\begin{array}{l}\text { Tidak memahami } \\
\text { maksud soal, } \\
\text { sehingga tidak } \\
\text { menjawab soal. }\end{array}$ & 1) & $\begin{array}{l}\text { Tidak mampu } \\
\text { mengubah bentuk } \\
\text { soal ke dalam } \\
\text { model matematika } \\
\text { Tidak paham } \\
\text { operasi yang } \\
\text { digunakan, } \\
\text { sehingga } \\
\text { menjumlahkan nilai } \\
\text { pembilang dan } \\
\text { menjumlahkan nilai } \\
\text { penyebut. }\end{array}$ & $\begin{array}{l}\text { 1) } \\
\text { 2) } \\
3) \\
\text { 4) } \\
\text { 4) } \\
\end{array}$ & $\begin{array}{l}\text { Hanya mengalikan } \\
\text { pembilang. } \\
\text { Mengalikan } \\
\text { pembilang dan } \\
\text { mengambil nilai } \\
\text { penyebut pada } \\
\text { pecahan pertama. } \\
\text { Mengalikan } \\
\text { pembilang dan } \\
\text { mengambil nilai } \\
\text { penyebut tertinggi } \\
\text { dari kedua } \\
\text { pecahan. } \\
\text { Melakukan } \\
\text { perkalian silang } \\
\text { (nilai pembilang } \\
\text { pada pecahan } \\
\text { pertama dikalikan } \\
\text { dengan nilai } \\
\text { penyebut pada } \\
\text { pecahan kedua } \\
\text { untuk nilai } \\
\text { pembilang pada } \\
\text { hasil operasi } \\
\text { hitung. Dan nilai } \\
\text { penyebut pada } \\
\text { pecahan pertama } \\
\text { dikalikan dengan } \\
\text { nilai pembilang } \\
\text { pada pecahan } \\
\text { kedua untuk nilai } \\
\text { penyebut pada } \\
\text { hasil operasi } \\
\text { hitung). }\end{array}$ & 1) $\begin{array}{l}\text { Tidak } \\
\text { mampu } \\
\text { membuat } \\
\text { kesimpulan } \\
\text { 2) }\end{array}$ \\
\hline 6 & $\begin{array}{l}\text { Operasi } \\
\text { pembagian } \\
\text { pecahan }\end{array}$ & $\begin{array}{l}\text { Tidak } \\
\text { menuliskan } \\
\text { apa yang } \\
\text { diketahui } \\
\text { dan apa } \\
\text { yang } \\
\text { ditanyakan }\end{array}$ & $\begin{array}{l}\text { Tidak memahami } \\
\text { maksud soal, } \\
\text { sehingga tidak } \\
\text { menjawab soal. }\end{array}$ & 1) & $\begin{array}{l}\text { Tidak mampu } \\
\text { mengubah bentuk } \\
\text { soal ke dalam } \\
\text { model matematika } \\
\text { Tidak paham } \\
\text { dengan operasi } \\
\text { pembagian, } \\
\text { sehingga } \\
\text { mengurangkan nilai }\end{array}$ & 1) & $\begin{array}{l}\text { Menyamakan } \\
\text { penyebut terlebih } \\
\text { dahulu, kemudian } \\
\text { mengubah pecahan } \\
\text { menjadi pecahan } \\
\text { senilai, kemudian } \\
\text { membagi } \\
\text { pembilang. } \\
\text { Melakukan }\end{array}$ & 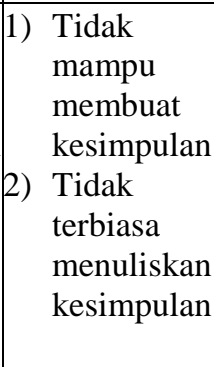 \\
\hline
\end{tabular}




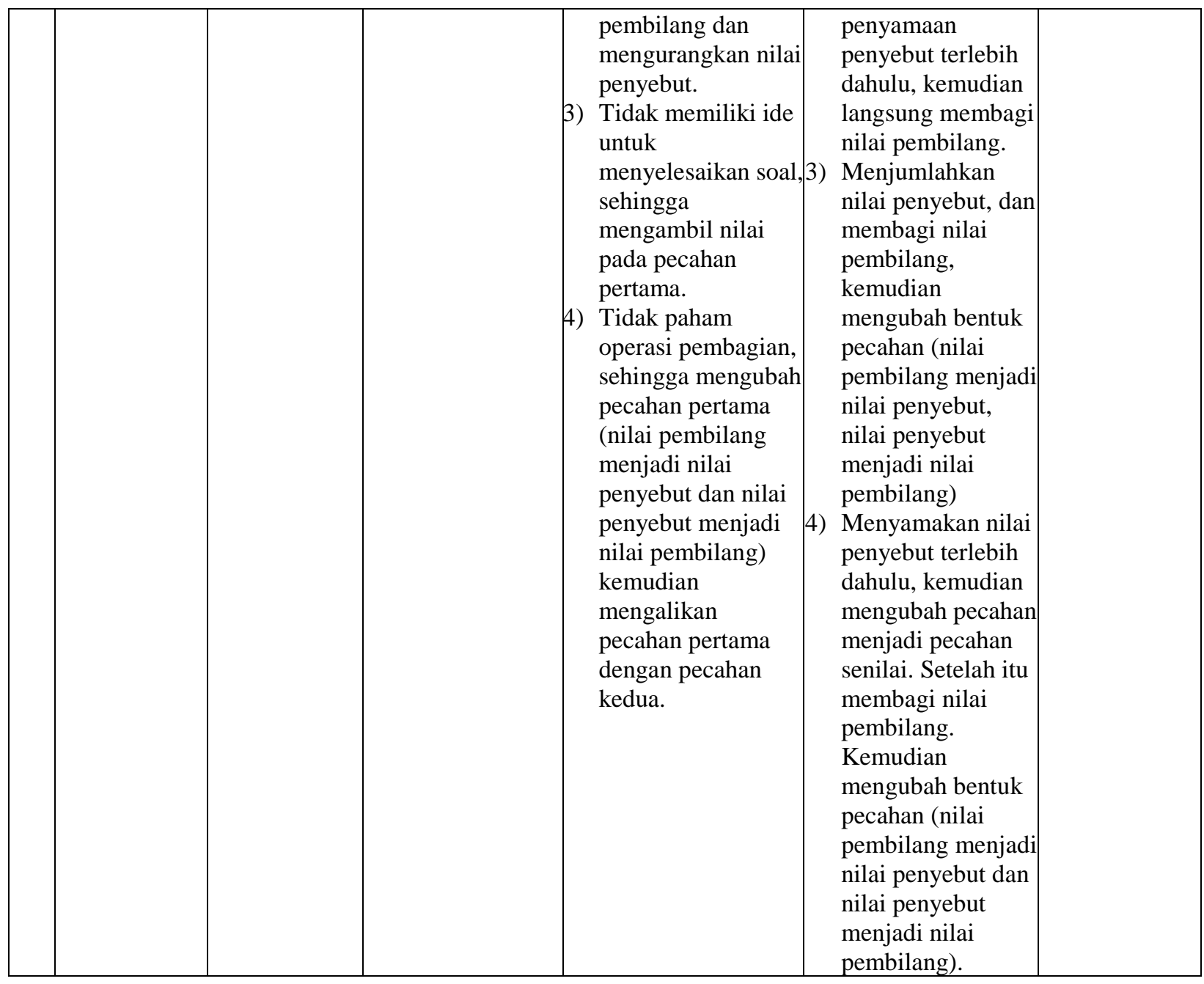

Selain kesalahan di atas, terdapat pula kesalahan kecerobohan/kelalaian yang dilakukan oleh siswa yaitu salah menghitung hasil operasi, padahal setelah dilakukan wawancara mereka mampu menjawab benar hasil perhitungan tersebut.

Setelah mendapatkan berbagai kesalahan-kesalahan yang dilakukan oleh siswa seperti pada tabel 2. Selanjutnya, pengelompokkan kesalahan tersebut dibuat dalam persentase dalam tiap nomor soal terhadap 65 siswa. Persentase tersebut disajikan dalam tabel berikut ini:

Tabel 3. Persentase kesalahan siswa tiap nomor berdasarkan jenis kesalahan dari 65 siswa

\begin{tabular}{ccccccc}
\hline Nomor & $\begin{array}{c}\text { Reading } \\
\text { Errors } \\
\text { soal }\end{array}$ & $\begin{array}{c}\text { Comprehension } \\
\text { Errors } \\
(\%)\end{array}$ & $\begin{array}{c}\text { Tranformation } \\
\text { Errors } \\
(\%)\end{array}$ & $\begin{array}{c}\text { Process } \\
\text { Skills } \\
\text { Errors } \\
(\%)\end{array}$ & $\begin{array}{c}\text { Encoding } \\
\text { Errors } \\
(\%)\end{array}$ & $\begin{array}{c}\text { Careless } \\
(\%)\end{array}$ \\
\hline 1. & 1,54 & 1,54 & 4,62 & 6,15 & 3,08 & 1,54 \\
2. & 4,62 & 9,23 & 6,15 & 43,08 & 4,62 & 1,54 \\
3. & 1,54 & 7,69 & 7,69 & 6,15 & 1,54 & 1,54 \\
4. & 1,54 & 3,08 & 44,62 & 30,77 & 3,08 & 1,54 \\
5. & 3,08 & 15,38 & 27,69 & 23,08 & 3,08 & 1,54 \\
6. & 4,62 & 33,85 & 9,23 & 40,00 & 4,62 & 6,15 \\
\hline
\end{tabular}


Dari tabel di atas, terlihat bahwa untuk soal nomor 1, Process Skills Errors yang paling banyak dilakukan yaitu sebesar $6,15 \%$. Untuk soal nomor 2, Process Skill Errors juga paling banyak dilakukan sebesar 43,08\%. Untuk soal nomor 3, Comprehension Errors dan Transformasion Errors sama-sama banyak dilakukan sebesar 7,69\%. Untuk soal nomor 5, Transformation Errors dilakukan sebesar 27,69\%. Untuk soal nomor 6, Process Skills Errors yang paling banyak dilakukan sebesar $40,00 \%$.

Dari 6 nomor soal, soal nomor 2 dan 6 yang paling banyak terjadi Reading Errors oleh siswa, yaitu 4,62\%, hal ini berarti, siswa banyak tidak dapat membaca kata kunci atau simbol yang tertulis dalam masalah matematika pada operasi penjumlahan pada pecahan yang penyebutnya tidak sama dan operasi pembagian pecahan. Untuk Comprehension Errors, paling banyak terjadi pada soal nomor 6, yaitu $33,85 \%$, hal ini menandakan bahwa siswa tidak memahami arti keseluruhan kata-kata sehingga siswa tidak mampu untuk melanjutkan penyelesaian masalah yang tepat pada soal mengenai operasi pembagian pecahan. Untuk Tranformation Errors, paling banyak terjadi pada soal nomor 4, sebesar 44,62\%, hal ini menandakan bahwa siswa tidak mampu mengidentifikasi operasi atau urutan operasi yang diperlukan untuk menyelesaikan masalah pada soal mengenai pengurangan penyebut berbeda. Untuk Process Skills Errors, paling banyak dilakukan pada soal nomor 2 yaitu sebesar 43,08\%, hal ini menandakan bahwa siswa tidak mengetahui prosedur yang diperlukan untuk melaksanakan operasi secara akurat pada soal mengenai penjumlahan berpenyebut berbeda. Dan untuk Encoding Errors, paling banyak dilakukan pada soal nomor 2 dan 6 , yaitu sebesar $4,62 \%$, hal ini menandakan bahwa siswa tidak mampu menyatakan solusi dalam bentuk notasi yang benar dan bisa diterima sebagai suatu kesimpulan pada soal mengenai penjumlahan berpenyebut berbeda dan soal pembagian pecahan. Serta untuk Careless, banyak terjadi pada soal nomor 6 mengenai operasi pembagian pecahan, yaitu 6,15\%.

Selanjutnya, penjabaran mengenai persentase kesalahan siswa berdasarkan pengelompokkan kesalahan dan operasi hitung pecahan yang disajikan pada tabel berikut ini:

Tabel 4. Persentase kesalahan siswa berdasarkan pengelompokkan kesalahan dan operasi hitung pecahan

\begin{tabular}{ccccccc}
\hline $\begin{array}{c}\text { Operasi } \\
\text { hitung } \\
\text { pecahan }\end{array}$ & $\begin{array}{c}\text { Reading } \\
\text { Errors } \\
(\%)\end{array}$ & $\begin{array}{c}\text { Comprehension } \\
\text { Errors } \\
(\%)\end{array}$ & $\begin{array}{c}\text { Tranformation } \\
\text { Errors } \\
(\%)\end{array}$ & $\begin{array}{c}\text { Process } \\
\text { Skills Errors } \\
(\%)\end{array}$ & $\begin{array}{c}\text { Encoding } \\
\text { Errors } \\
(\%)\end{array}$ & $\begin{array}{c}\text { Careless } \\
(\%)\end{array}$ \\
\hline Penjumlahan & 6,15 & 10,77 & 10,77 & 49,23 & 7,69 & 3,08 \\
Pengurangan & 3,08 & 10,77 & 52,31 & 36,92 & 4,62 & 3,08 \\
Perkalian & 3,08 & 15,38 & 27,69 & 23,08 & 3,08 & 1,54 \\
Pembagian & 4,62 & 33,85 & 9,23 & 40,00 & 4,62 & 6,15 \\
\hline
\end{tabular}

Berdasarkan tabel di atas, terlihat bahwa untuk operasi penjumlahan pecahan, kesalahan yang paling banyak dilakukan adalah Process Skills Errors sebesar 49,23\%. Untuk operasi pengurangan pecahan, kesalahan yang paling banyak dilakukan adalah Tranformation Errors sebesar 52,31\%. Operasi perkalian pecahan, kesalahan yang paling banyak dilakukan adalah Tranformation Errors sebesar 27,69\%. Dan untuk operasi pembagian pecahan, kesalahan yang paling banyak dilakukan adalah Process Skills Errors sebesar 40,00\%. 
Berdasarkan penyajian data hasil penelitian, maka diperoleh bahwa soal cerita yang paling banyak dijawab benar adalah soal mengenai operasi penjumlahan yang memiliki penyebut sama. Sedangkan untuk soal cerita mengenai operasi pembagian pecahan, banyak dijawab salah oleh siswa. Hal ini menandakan bahwa, siswa lebih paham terhadap soal cerita mengenai operasi penjumlahan daripada soal cerita yang menggunakan operasi pembagian pecahan. Penyebabnya, untuk operasi penjumlahan pecahan (khususnya yang berpenyebut sama), selain cara menyelesaikan soalnya langsung melakukan operasi (penjumlahan) pada nilai pembilang tanpa memperhatikan nilai penyebut, bahasa dan cara menganalisis soalnya juga lebih gampang dipahami daripada operasi pembagian. Sedangkan untuk operasi pembagian pecahan, selain cara yang dilakukan adalah dengan mengubah pecahan kedua (nilai pembilang menjadi nilai penyebut dan nilai penyebut menjadi nilai pembilang) kemudian mengalikan kedua pecahan, bahasa dan cara menganalisis soalnya susah dipahami oleh siswa, karena pada soal cerita untuk operasi pembagian, siswa dituntut lebih dalam menganalisis dan berpikir kritis dalam menyelesaikan soal tersebut.

Berdasarkan hasil penelitian, untuk operasi penjumlahan pecahan, kesalahan yang paling banyak dilakukan adalah Process Skills Errors sebesar 49,23\%. Hal ini berarti siswa masih perlu banyak belajar tentang mengenali operasi yang tepat atau urutan operasi, dan memperhatikan prosedur yang diperlukan untuk melaksanakan operasi secara akurat, khususnya pada operasi penjumlahan pecahan. Untuk operasi pengurangan pecahan, kesalahan yang paling banyak dilakukan adalah Tranformation Errors sebesar 52,31\%. Karena Tranformation Errors yang paling banyak dilakukan, sehingga siswa perlu lebih teliti dalam mengidentifikasi operasi atau urutan operasi yang diperlukan untuk menyelesaikan masalah pada soal mengenai pengurangan pecahan. Operasi perkalian pecahan, kesalahan yang paling banyak dilakukan adalah Tranformation Errors sebesar 27,69\%. Hal ini berarti, siswa perlu lebih teliti dalam mengidentifikasi operasi atau urutan operasi yang diperlukan untuk menyelesaikan masalah pada soal mengenai perkalian pecahan. untuk operasi pembagian pecahan, kesalahan yang paling banyak dilakukan adalah Process Skills Errors sebesar 40,00\%. Hal ini berarti, siswa masih perlu banyak belajar tentang mengenali operasi yang tepat atau urutan operasi, dan memperhatikan prosedur yang diperlukan untuk melaksanakan operasi secara akurat, khususnya pada operasi pembagian pecahan. Dari data tersebut diperoleh bahwa untuk operasi penjumlahan dan pembagian pecahan, kesalahan yang paling banyak dilakukan adalah Process Skills Errors. Berbeda dengan operasi pengurangan dan perkalian pecahan, kesalahan yang paling banyak dilakukan adalah Tranformation Errors. Hal ini, sejalan dengan Idris dan Narayanan (2011) yang melakukan penelitian pada 80 siswa kelas II SMP di negara bagian Selangor. Temuan penelitiannya menunjukkan bahwa kesalahan dalam operasi penjumlahan ialah 29,8\%, kesalahan kecerobohan/kelalaian adalah 26,3\%, dan kesalahan acak 11,1\%. Dalam kesalahan sistematis, 50,6\% siswa memiliki masalah konversi, 26,2\% mengalami masalah dalam pemahaman, dan $14,9 \%$ berkaitan dengan menyelesaikan masalah pecahan dengan tidak tepat. Adapun pengurangan pecahan, terdapat 26,4\% kesalahan sistematis, 10,3\% kesalahan kecerobohan/kelalaian, dan 2,5\% kesalahan acak. Dalam kesalahan sistematis $47,9 \%$ siswa menghadapi masalah dalam hal pemahaman.

Dari keseluruhan soal cerita pada operasi hitung pecahan, dan dari keenam jenis kesalahan yang dilakukan, Process Skills Errors menempati urutan pertama 
yang dilakukan oleh siswa dalam menyelesaikan 6 nomor soal mengenai operasi hitung pecahan, yaitu sebesar 40,25\%. Selanjutnya diikuti oleh Tranformasion Errors sebesar 26,97\%, Comprehension Errors sebesar 19,09\%, Encoding Errors sebesar 5,39\%, dan Reading Errors sebesar 4,56\%, serta Careless dilakukan sebesar $3,73 \%$. Hal ini berarti siswa kelas V SDN Pengawu masih perlu banyak belajar tentang mengenali operasi hitung pecahan yang tepat atau urutan operasi, dan memperhatikan prosedur yang diperlukan untuk melaksanakan operasi hitung pecahan secara akurat. Karena sesuai dengan pendapat Lusiana (2017:25) dengan adanya kesalahan-kesalahan matematika yang dilakukan oleh peserta didik, maka akan berdampak kepada penurunan nilai siswa dalam mata pelajaran matematika.

\section{SIMPULAN DAN SARAN}

Dari keseluruhan tes mengenai operasi hitung pecahan yang telah diberikan kepada 65 siswa kelas V SDN Pengawu, diperoleh bahwa kesalahan yang paling banyak dilakukan siswa yaitu Process Skills Errors sebesar 40,25\%. Selanjutnya diikuti oleh Tranformasion Errors sebesar 26,97\%, Comprehension Errors sebesar 19,09\%, Encoding Errors sebesar 5,39\%, dan Reading Errors sebesar 4,56\%, serta Careless dilakukan sebesar 3,73\%. Untuk operasi penjumlahan pecahan, kesalahan yang paling banyak dilakukan adalah Process Skills Errors sebesar 49,23\%. Untuk operasi pengurangan pecahan, kesalahan yang paling banyak dilakukan adalah Tranformation Errors sebesar 52,31\%. Operasi perkalian pecahan, kesalahan yang paling banyak dilakukan adalah Tranformation Errors sebesar 27,69\%. Dan untuk operasi pembagian pecahan, kesalahan yang paling banyak dilakukan adalah Process Skills Errors sebesar 40,00\%.

Penelitian ini diharapkan dapat menjadi acuan bagi para pendidik agar dapat lebih memperhatikan model atau metode mengajar di kelas agar dapat meminimalisir kesalahan yang dibuat oleh siswa, baik kesalahan konsep, prinsip, fakta, maupun prosedural. Selain itu dapat dijadikan acuan untuk peneliti-peneliti selanjutnya untuk melakukan penelitian sejenis.

\section{DAFTAR PUSTAKA}

Abdullah, A. H., Abidin, N.L. Zainal, dan Ali, Marlina. 2015. Analysis of Students' Errors in Solving Higher Order Thinking Skills (HOTS) Problems for Topic of Fraction. Asian Social Science, Vol. 11(21). ISSN: 1911 - 2017, E - ISSN: 1911 - 2025. Tersedia : www.ccsenet.org/ass

Amalia, S.R. 2017. Analisis Kesalahan Berdasarkan Prosedur Newman dalam Menyelesaikan Soal Cerita Ditinjau dari Gaya Kognitif Mahasiswa. Jurnal Aksioma, Vol. 8(1) : 17-30. e-ISSN 2579 - 7646.

Cahyono, N.D. 2017. Analisis Kesalahan Jawaban Siswa dalam Menyelesaikan Soal Cerita Materi Pecahan berdasarkan Kategori Kesalahan Newman di SMP Negeri 2 Sawit. Skripsi tidak diterbitkan. Surakarta: Program Studi Pendidikan Matematika, FKIP Universitas Muhammadiyah Surakarta.

Herholdt, R., and Sapire, I. 2014. An Error Analysis in the Early Grades Mathematics - A Learning Opportunity? South African Journal of Childhood Education, Vol. 4(1) : 42 - 60. ISSN: 2223 - 7674.

Idris, S. and Narayanan, L. M. 2011. Error Patterns in Addition and Subtraction of Fractions among Form Two Students. Journal of Mathematics Education, Vol. $4(2): 35$ - 54. Tersedia : www.educationforatoz.com/images/Idris.pdf 
Juliyanti. 2016. Analisis Kesalahan Siswa dalam Menyelesaikan Soal Cerita Matematika Materi Pecahan pada Siswa Kelas IV di SD Negeri Se-gugus Lodan Semarang Utara. Skripsi tidak diterbitkan. Semarang: Jurusan Pendidikan Guru Sekolah Dasar, Fakultas Ilmu Pendidikan Universitas Negeri Semarang.

Lusiana, R. 2017. Analisis Kesalahan Mahasiswa dalam Memecahkan Masalah pada Materi Himpunan ditinjau dari Gaya Kognitif. Jurnal Penelitian dan Pembelajaran Matematika, Vol. 10(1) : 24 - 29.

Saputro, Bagus Ardi. 2016. Kemampuan Penalaran Matematis Siswa yang Belajar Operasi Pecahan Menggunakan Permainan Tradisional. Jurnal Penelitian dan Pembelajaran Matematika, Vol. 9(1): 63 - 72.

Suciati, I. 2010. Penerapan Gaya Belajar Model Kolb untuk Meningkatkan Hasil Belajar Siswa pada Materi Keliling dan Luas Daerah Lingkaran di Kelas VIII A SMP Negeri 10 Palu. Skripsi tidak diterbitkan. Palu: Program Studi Pendidikan Matematika FKIP Universitas Tadulako.

Sugiyono. 2013. Metode Penelitian Pendidikan (Pendekatan Kuantitatif, Kualitatif, dan $R \& D$ ). Bandung : CV. Alfabeta. 